\title{
Vero cytotoxin-producing strains of Escherichia coli from children with haemolytic uraemic syndrome and their detection by specific DNA probes
}

\author{
S. M. SCOTLAND, B. ROWE*, H. R. SMITH, G. A. WILLSHAW and R. J. GROSS
}

Division of Enteric Pathogens, Central Public Health Laboratory, 61 Colindale Avenue, London NW9 5HT

\begin{abstract}
Summary. Faecal specimens from 66 children with haemolytic uraemic syndrome in the United Kingdom were examined for strains of Escherichia coli producing Vero cytotoxin (VT). Initially, conventional bacteriological methods were used to identify colonies of $E$. coli which were then tested for VT production. Subsequently, specific DNA probes for VT1 and VT2 were used in hybridisation tests to detect VTproducing E. coli (VTEC). VTEC strains were isolated from 19 cases and in 15 they belonged to serogroup O157. Fourteen of these O157 strains possessed the flagellar antigen $\mathrm{H} 7$ and one was non-motile. The VTEC strains from the remaining four cases belonged to serotypes $\mathrm{O} 26: \mathrm{H} 11, \mathrm{O} 104: \mathrm{H} 2, \mathrm{O} 153: \mathrm{H} 25$, and $\mathrm{O} 163: \mathrm{H} 19$ together with a rough $\mathrm{VT}^{+}$strain with flagellar antigen $\mathrm{H} 51$. The $\mathrm{O} 157$ strains hybridised with either the VT2 probe or both VT1 and VT2 probes. The other VTEC strains hybridised with either the VT1 or VT2 probe. Confirmation of the production of VT1 and VT2 in vivo was obtained by the neutralisation of faecal VT with specific antisera raised against these two cytotoxins.
\end{abstract}

\section{Introduction}

Haemolytic uraemic syndrome (HUS) comprises micro-angiopathic haemolytic anaemia, thrombocytopenia and acute renal failure (von Gasser et al., 1955). HUS occurs in all age groups but most commonly in infants and young children in whom it is recognised as an important cause of renal failure (Levin and Barratt, 1984). The disease may present in several forms (Levin and Barratt, 1984; Drummond, 1985). A well-recognised presentation with prodromal bloody diarrhoea occurs in the summer months in young children and infants. Intra-familial spread and geographically related clusters suggest an infective aetiology. Various bacteria, viruses and rickettsiae have been implicated but the relationship of these organisms with the disease is uncertain. Infection with Shigella dysenteriae type 1 can lead to HUS (Koster et al., 1978) and, during an outbreak of dysentery in Bangladesh, HUS was a frequent complication (Rahaman et al., 1975).

Certain strains of Escherichia coli produce a cytotoxin (VT) active on Vero cells that is distinct from the heat-labile enterotoxin (LT) and the heatstable enterotoxin (ST) (Konowalchuk et al., 1977).

Received 23 Oct. 1986; accepted 15 March 1987.

* Requests for offprints should be sent to Dr B. Rowe.
Neutralisation studies indicate that there is more than one VT (Konowalchuk et al., 1977, 1978b; Smith et al., 1983; Scotland et al., 1985; Karmali et al., 1986). One VT is neutralised by a rabbit antiserum prepared against Shiga toxin (O'Brien $e t$ $a l ., 1982$ ) and we proposed that this be termed VT1 and the VT produced by strain E32511, of serogroup O157, be termed VT2 (Scotland et al., 1985). Some strains of serogroup O157, including strain E32511, produced only VT2, whereas others produced VT1 and VT2 (Scotland et al., 1985). Production of VT has been shown to be phage-mediated (Scotland et al., 1983; Smith et al., 1983; O'Brien et al., 1984; Smith et al., 1984) and specific VT probes have been developed for use in DNA hybridisation tests (Newland et al., 1985; Willshaw et al., 1985, 1987; Huang et al., 1986). Under stringent conditions, no cross hybridisation was detected between VT1 and VT2 probes developed from appropriate VTproducing strains (Willshaw et al., 1987).

In 1983, Karmali et al. reported the isolation of VT-producing $\left(\mathrm{VT}^{+}\right)$strains of $E$. coli from cases of HUS in Canada. Also in 1983, an outbreak of HUS occurred in the West Midland area of England. There was no evidence of infection by salmonellae shigellae, campylobacters or viruses (Gully, 1984); however, studies in this laboratory showed that $\mathrm{VT}^{+}$strains of $E$. coli $\mathrm{O} 157: \mathrm{H} 7$ were isolated from faeces in several cases (Taylor et al., 
1986). A prospective study was subsequently carried out to investigate the possible association between VTEC infection and HUS in the United Kingdom and the bacteriological findings are reported here.

\section{Materials and methods}

\section{Subjects}

From August 1983 to May 1985, 66 patients, aged between 3 weeks and 11 years, with HUS were admitted to the study. The patients were from many areas of the United Kingdom; five were children from the West Midlands outbreak of 1983 (Gully, 1984; Taylor et al., 1986).

\section{Identification of VTEC in faeces}

In phase 1 (August 1983 to December 1983), specimens from 23 patients were studied by culture on MacConkey Agar (Oxoid; CM115). Representative lactose-fermenting and non-fermenting colonies were selected for further examination and were identified biochemically (Cowan, 1974). Up to 40 colonies identified as $E$. coli were serotyped (Gross and Rowe, 1985) and screened for the production of VT; any production of VT was confirmed by tests with sterile culture supernates as described below.

In phase 2 (January 1984 to November 1984), 32 patients were studied. Up to 40 colonies of $E$. coli were tested for VT production, but only those which proved to be $\mathrm{VT}^{+}$were serotyped. In addition, the faecal specimens were plated out to give colonies which were examined with DNA probes specific for VT genes.

In phase 3 (December 1984 to May 1985), 11 faecal specimens were examined for the presence of VTEC with DNA probes only. Probe-positive colonies were confirmed as $E$. coli by biochemical tests and their serotype was determined; sterile culture supernates were also tested for VT production.

The strains of $E$. coli isolated in phase 1 were tested retrospectively with the two DNA probes for VT1 and VT2.

\section{Tests for resistance to antibacterial drugs}

Strains were tested by the method of Anderson and Threlfall (1974) for resistance to amikacin, ampicillin, ceftazidime, cephaloridine, cephalexin, chloramphenicol, colistin, furazolidone, gentamicin, kanamycin, mecillinam, nalidixic acid, netilmicin, spectinomycin, streptomycin, sulphathiazole, tetracycline, tobramycin and trimethoprim.

\section{Testing for free cytotoxin in faeces}

In all three phases, the presence of free cytotoxin in the faecal specimens was investigated as described by Karmali et al. (1983). Dilutions in tissue-culture medium (see below) of a faecal filtrate were tested for cytotoxic activity on Vero cells and Y1 mouse adrenal tumour cells growing as monolayers in 96-well tissue culture microtitration plates. Cytotoxic activity was expressed as the highest dilution which had a detectable cytotoxic effect on a monolayer of cells after incubation for 4 days at $37^{\circ} \mathrm{C}$. The cytotoxic effect was considered to be specific for Vero cells, that is VT, if it had no effect on Y1 cells. Vero cells were grown on E199 medium (Flow Laboratories) supplemented with fetal calf serum $10 \%$. Y1 cells were grown on F10 medium (Flow Laboratories) supplemented with horse serum $12.5 \%$ and fetal calf serum $2 \cdot 5 \%$.

\section{Testing bacterial cultures for VT and other enterotoxins}

Large numbers of colonies were screened for VT production by a rapid method (Willshaw et al., 1985). To confirm VT production, sterile culture supernates of bacteria grown in Trypticase Soy Broth (BBL) were tested as described previously (Scotland et al., 1980). All VT ${ }^{+}$ strains, and, in phase 1 , a colony representative of each serotype isolated from a patient, were tested for the production of ST and LT (Gross et al., 1976). All VT ${ }^{+}$ strains were also tested for invasiveness by a tissueculture method (Day et al., 1981).

\section{Neutralisation of faecal cytotoxin}

An antiserum to Shiga toxin to neutralise VT1 and an antiserum to VT2, produced by strain E32511 (E. coli O157:H-) were used to test for neutralisation of faecal cytotoxins. The antiserum to purified Shiga toxin was prepared in rabbits and was received from Dr A. D. O'Brien. The antiserum raised against partially purified VT2 (Scotland et al., 1985) was prepared in rabbits according to the method of Konowalchuk et al. (1978a). Dilutions of the faecal cytotoxin $(25 \mu \mathrm{l})$ were added to $0.2 \mathrm{ml}$ of the Vero-cell tissue-culture medium alone or with 20 units of each antiserum separately or with 20 units of both antisera together. After $3 \mathrm{~h}$ at $37^{\circ} \mathrm{C}$ and $18 \mathrm{~h}$ at $4^{\circ} \mathrm{C}$ these preparations were added to a monolayer of Vero cells in microtitration plate wells. After incubation for 4 days at $37^{\circ} \mathrm{C}$ the monolayers were examined to determine whether the cytotoxic titre was decreased by the presence of one or both antisera. A unit of antibody was defined as the amount present in the highest dilution of antiserum which neutralised 1-5 units of VT. A unit of VT activity was defined as the amount present in the highest dilution of a toxin preparation which caused any cytotoxic effect in the otherwise completely confluent monolayer of Vero cells.

\section{Preparation of faecal specimens for DNA hybridisation}

Faecal specimens were re-suspended in an equal volume of PBS and diluted to $10^{7}$-fold. Samples $(0 \cdot 1 \mathrm{ml})$ 
of each dilution were spread on MacConkey agar and the plates were incubated overnight at $37^{\circ} \mathrm{C}$. For each sample a plate with several hundred well-separated colonies was replicated on to nitrocellulose (Schleicher and Schull BA85) or nylon (Amersham Hybond-N) membranes placed on the surface of MacConkey agar plates. The master plates and the replicas were incubated at $37^{\circ} \mathrm{C}$ for at least $6 \mathrm{~h}$. The membranes were processed for hybridisation by placing on a series of 3MM papers saturated with the following solutions: SDS $10 \%(5 \mathrm{~min})$, lysis solution containing $0.5 \mathrm{M} \mathrm{NaOH}$ and $1.5 \mathrm{M} \mathrm{NaCl}(5-10$ min), neutralising solution containing $1.5 \mathrm{M} \mathrm{NaCl}$ and $0.5 \mathrm{M}$ Tris- $\mathrm{HCl}, p \mathrm{H} 8.0(5 \mathrm{~min})$, and finally $2 \times \mathrm{SSPE}(5$ min). SSPE contained $0.3 \mathrm{M} \mathrm{NaCl}, 17.5 \mathrm{mM} \mathrm{NaH}{ }_{2} \mathrm{PO}_{4}$ and $2.2 \mathrm{mM}$ EDTA. The membranes were left to dry at room temperature. Nitrocellulose membranes were baked for $2 \mathrm{~h}$ at $80^{\circ} \mathrm{C}$ and nylon membranes were wrapped in cling film and placed on a UV transilluminator (wavelength $365 \mathrm{~nm}$ ) for $4 \mathrm{~min}$.

\section{Preparation of DNA probes}

A HincII fragment of $0.75 \mathrm{~kb}$ was used as a probe specific for VT1 sequences. It was obtained by cloning from a VT-encoding phage carried by strain H19, E. coli O26: H11 (Willshaw et al., 1985). The colonies from faecal platings were tested for VT2-specific sequences by hybridisation with a $2 \mathrm{~kb} H$ incII fragment that was identified in cloning experiments from a phage carried by strain E32511, E. coli O157:H- (Smith et al., 1984; Willshaw et al., 1985). VTEC that hybridised with the 2 kb HincII probe were tested again with a more specific VT2 probe comprising a $0.85 \mathrm{~kb}$ AvaI-Pst I fragment developed from the VT phage in E32511 (Willshaw et al., 1987). Fragments for use as probes were prepared by electro-elution from agarose or acrylamide-agarose gels, purified with Elutip minicolumns (Schleicher and Schull) and labelled by nick translation with deoxyadenosine 5'$\alpha-\left[{ }^{35}\right.$ S $]$ thiotriphosphate (Amersham).

\section{Hybridisation experiments}

Hybridisation with ${ }^{35} \mathrm{~S}$-labelled VT probes was performed under stringent conditions and filters were prepared for autoradiography as described previously (Willshaw et al., 1985). The autoradiographs were examined together with the original plates, and colonies that hybridised with the VT probe or probes were identified. These were tested for VT production and identified biochemically and serologically. Up to ten probe-positive colonies were tested from each faecal sample. On some plates it was difficult to identify an individual probe-positive colony, so a number were picked and re-tested by hybridisation until a separate probe-positive colony was obtained.

\section{Results}

\section{Identification of VTEC or specific cytotoxin (VT) in faecal specimens}

Twenty-three patients were studied in phase 1 and VTEC strains were isolated from seven (table I), including two from the West Midlands outbreak (patients 2 and 3). Only $\mathrm{VT}^{-}$strains of E. coli were isolated from 12 patients and $E$. coli could not be isolated from the remaining four. Thirty-two patients were studied in phase 2 and VTEC strains were isolated from nine (table II). Only $\mathrm{VT}^{-}$strains of $E$. coli were isolated from 20 patients and $E$. coli could not be isolated from the remaining three. In this second phase, two methods were used for the detection of VTEC and in all but two cases they agreed; for patients 28 and 40, VTEC were detected only with the specific DNA probes which hybridised respectively with two of 270 and one of 1200 colonies growing on MacConkey-agar plates. Eleven patients were studied in phase 3 ; VTEC

Table I. Examination of faecal specimens in phase 1

\begin{tabular}{|c|c|c|c|c|c|c|c|c|}
\hline \multirow{2}{*}{$\begin{array}{l}\text { Patient } \\
\text { no. }\end{array}$} & \multirow[b]{2}{*}{ Sex } & \multirow[b]{2}{*}{ Age } & \multirow{2}{*}{$\begin{array}{l}\text { Geographical } \\
\text { location }\end{array}$} & \multirow{2}{*}{$\begin{array}{l}\mathrm{VT}^{+} \text {E. coli iso- } \\
\text { lated by picking } \\
\text { colonies } \\
(\%)\end{array}$} & \multirow{2}{*}{$\begin{array}{l}\text { Titre of VT } \\
\text { in faecal } \\
\text { specimens }\end{array}$} & \multirow{2}{*}{$\begin{array}{l}\text { Serotype of } \mathrm{VT}^{+} \\
\text {E. coli }\end{array}$} & \multicolumn{2}{|c|}{$\begin{array}{l}\text { Results of } \mathrm{VT}^{+} E \text {. coli with } \\
\text { DNA probe* for }\end{array}$} \\
\hline & & & & & & & VT1 & VT2 \\
\hline 2 & $\mathrm{~F}$ & $15 \mathrm{mo}$ & Wolverhampton & 8 & NA & $\mathrm{O} 157: \mathrm{H} 7$ & - & + \\
\hline 3 & M & $17 \mathrm{mo}$ & Wolverhampton & 100 & NA & O157:H7 & - & + \\
\hline 6 & $\mathrm{~F}$ & $16 \mathrm{mo}$ & Salisbury & 22 & NA & $\mathrm{O} 157: \mathrm{H} 7$ & + & + \\
\hline 11 & $\mathrm{~F}$ & $6 \mathrm{yr}$ & Peterborough & 95 & 40 & $\mathrm{O} 157: \mathrm{H} 7$ & - & + \\
\hline 19 & F & $4 \mathrm{mo}$ & Southampton & 80 & 5120 & $\begin{array}{l}\text { O163: } \mathrm{H} 19 \text { and } \\
\text { O rough: } \mathrm{H} 51\end{array}$ & - & $\begin{array}{l}+ \\
+\end{array}$ \\
\hline 20 & $\mathrm{~F}$ & $5 \mathrm{mo}$ & Belfast & 85 & 640 & O153:H25 & - & + \\
\hline 23 & $\mathrm{~F}$ & $16 \mathrm{mo}$ & Birmingham & 18 & 40 & $\mathrm{O} 157: \mathrm{H}-$ & - & + \\
\hline
\end{tabular}

*VT1, 0.75 kb HinclI fragment; VT2, $0.85 \mathrm{~kb}$ AvaI-PstI fragment (see Methods). $\mathrm{NA}=$ Not available for test. 
Table II. Examination of faecal specimens in phase 2

\begin{tabular}{|c|c|c|c|c|c|c|c|c|c|}
\hline \multirow[b]{2}{*}{$\begin{array}{l}\text { Patient } \\
\text { no. }\end{array}$} & \multirow[b]{2}{*}{ Sex } & \multirow[b]{2}{*}{ Age } & \multirow[b]{2}{*}{$\begin{array}{l}\text { Geographical } \\
\text { location }\end{array}$} & \multirow{2}{*}{$\begin{array}{l}\mathrm{VT}^{+} E . \text { coli } \\
\text { isolated by } \\
\text { picking } \\
\text { colonies } \\
(\%)\end{array}$} & \multirow{2}{*}{$\begin{array}{l}\text { DNA probe } \\
\text { tests on fae- } \\
\text { cal platings }\end{array}$} & \multirow{2}{*}{$\begin{array}{l}\text { Titre of VT } \\
\text { in faecal } \\
\text { specimens }\end{array}$} & \multirow{2}{*}{$\begin{array}{l}\text { Serotype of } \\
\mathrm{VT}^{+} \text {or } \\
\text { probe posi- } \\
\text { tive E. coli }\end{array}$} & \multicolumn{2}{|c|}{$\begin{array}{l}\text { Results of } E \text {. coli with } \\
\text { DNA probes }\end{array}$} \\
\hline & & & & & & & & VT1 & VT2 \\
\hline 24 & $\mathbf{M}$ & Child & Oxford & 3 & + & $20^{\mathrm{a}}$ & $\begin{array}{l}\mathrm{O} 104: \mathrm{H} 2 \\
\mathrm{O} ?: \mathrm{H} 25\end{array}$ & - & $\begin{array}{l}+ \\
-\end{array}$ \\
\hline 28 & $\mathbf{M}$ & Child & London & 0 & + & $20^{\mathrm{a}}$ & $\mathrm{O} 157: \mathrm{H} 7$ & + & + \\
\hline 40 & $\mathbf{F}$ & $10 \mathrm{yr}$ & Gt. Yarmouth & 0 & + & $<20$ & $\mathrm{O} 157: \mathrm{H} 7$ & - & + \\
\hline 41 & $\mathbf{M}$ & $9 \mathrm{yr}$ & Ipswich & 17 & + & 780000 & $\mathrm{O} 157: \mathrm{H} 7$ & - & + \\
\hline 45 & $\mathbf{F}$ & $1 \mathrm{yr}$ & Birmingham & 13 & + & 300000 & $\mathrm{O} 26: \mathrm{H} 11$ & + & - \\
\hline 48 & $\mathrm{~F}$ & $17 \mathrm{mo}$ & Cardiff & 10 & + & 60000 & $\mathrm{O} 157: \mathrm{H} 7$ & + & + \\
\hline 50 & $\mathrm{M}$ & $14 \mathrm{mo}$ & Burton-on-Trent & 80 & + & 20 & O157:H7 & - & + \\
\hline 51 & M & $11 \mathrm{mo}$ & London & 27 & + & $20^{\mathrm{a}}$ & O157:H7 & - & + \\
\hline 52 & $\mathrm{~F}$ & $11 \mathrm{yr}$ & London & 3 & + & NA & $\mathrm{O} 157: \mathrm{H} 7$ & - & + \\
\hline
\end{tabular}

${ }^{a}$ Cytotoxin was not specific for Vero cells.

${ }^{\mathrm{b}}$ This strain hybridised with the VT1 probe alone but did not produce Vero cytotoxin (see text).

NA $=$ Not available for test.

$\mathrm{O} ?=\mathrm{O}$ antigen could not be identified using antisera for serogroups $\mathrm{O} 1$ to $\mathrm{O} 170$.

Table III. Examination of faecal specimens in phase 3

\begin{tabular}{|c|c|c|c|c|c|c|c|c|}
\hline \multirow{2}{*}{$\begin{array}{l}\text { Patient } \\
\text { no. }\end{array}$} & \multirow[b]{2}{*}{ Sex } & \multirow[b]{2}{*}{ Age } & \multirow{2}{*}{$\begin{array}{l}\text { Geographical } \\
\text { location }\end{array}$} & \multirow{2}{*}{$\begin{array}{l}\text { DNA probe } \\
\text { tests on faecal } \\
\text { platings }\end{array}$} & \multirow{2}{*}{$\begin{array}{l}\text { Titre of VT in } \\
\text { faecal specimens }\end{array}$} & \multirow{2}{*}{$\begin{array}{l}\text { Serotype of probe } \\
\text { positive E. coli }\end{array}$} & \multicolumn{2}{|c|}{$\begin{array}{c}\text { Results of } \mathrm{VT}^{+} \text {E. coli with } \\
\text { DNA probes }\end{array}$} \\
\hline & & & & & & & VT1 & VT2 \\
\hline 59 & M & Child & Birmingham & + & 250 & O157:H7 & - & + \\
\hline 60 & $\mathrm{~F}$ & $14 \mathrm{mo}$ & Birmingham & + & NA & O157:H7 & + & + \\
\hline 66 & $\mathbf{M}$ & $6 \mathrm{yr}$ & Birmingham & + & 40 & O157:H7 & + & + \\
\hline
\end{tabular}

$\mathrm{NA}=$ Not available for test

strains were isolated from three (table III) and $\mathrm{VT}^{-}$ E. coli from eight.

Fourteen of the 19 faecal specimens from which VTEC strains were isolated were also tested for the presence of free faecal VT (tables I-III). In ten specimens, VT was detected, at titres in the range 20-780 000. In four, VT was not found but a nonspecific cytotoxin was present in three which may have masked low levels of VT. Forty two faecal specimens from which VTEC had not been isolated were also tested for free faecal VT. VT was detected in only three at titres of 80,100 and 500 . A nonspecific cytotoxin was observed at a low titre of 20 in another seven faecal specimens but it was not investigated further.

Table IV summarises the results from all three phases in which a total of 66 patients was studied. VTEC strains were isolated from 19 patients and free faecal VT was detected in 13. By combining the results of both tests, evidence of infection by VTEC was obtained for 22 of the 66 patients $(33 \%)$.

Faecal cultures for salmonellae, shigellae and campylobacters had been undertaken in the clinical

Table IV. Summary of HUS study

\begin{tabular}{ccccr}
\hline Study & $\begin{array}{c}\text { Number of } \\
\text { patients } \\
\text { studied }\end{array}$ & $\begin{array}{c}\text { Numbers } \\
\text { with VT } \\
E . \text { coli } \\
(\%)\end{array}$ & $\begin{array}{c}\text { Faeces posi- } \\
\text { tive for VT } \\
(\%)\end{array}$ & $\begin{array}{c}\text { Total } \\
\text { positive } \\
(\%)\end{array}$ \\
\hline 1 & 23 & $7 / 19(37)$ & $5 / 18(28)$ & $8 / 23(35)$ \\
2 & 32 & $9 / 30(30)$ & $5 / 30(17)$ & $10 / 32(31)$ \\
3 & 11 & $3 / 11(27)$ & $3 / 8(38)$ & $4 / 11(36)$ \\
Total & 66 & $19 / 60(32)$ & $13 / 56(23)$ & $22 / 66(33)$
\end{tabular}

NT $=$ Not tested.

Not every specimen could be studied by both methods; in each ratio the number of positive tests and the number tested is given. 
laboratories and these pathogens were reported to be absent except for patient 41 whose faeces yielded a Salmonella sp.

\section{Properties of E. coli isolated from faecal specimens}

VTEC strains were isolated from 19 of the 66 patients with HUS and in 15 cases these belonged to serogroup $0157 ; 14$ possessed the flagellar antigen $\mathrm{H} 7$ and one strain (E32511) was non-motile. The E. coli $\mathrm{O} 157$ strains were of two groups with respect to hybridisation with the DNA probes (tables I-III). Ten strains (including E32511 from which the probe was developed) hybridised only with the VT2 probe, and five strains hybridised with both VT1 and VT2 probes. The two O157 strains isolated from the West Midlands outbreak belonged to the class hybridising only with the VT2 probe.

From the faeces of patient 19, VTEC of two serotypes, O163:H19 and O rough:H51, were isolated; both hybridised with the VT2 probe only (table I). The remaining three patients from whom VTEC strains were isolated yielded strains of $E$. coli of serotypes O26:H11, O104:H2 and O153:H25, respectively; the first of these hybridised with the VT1 probe only and the second and third hybridised with the VT2 probe only (tables I and II).

The VTEC strains isolated in this study did not produce ST or LT, and they gave negative results in the test for invasiveness, in agreement with previous reports (Johnson et al., 1983; Riley et al., 1983; Wells et al., 1983; Karmali et al., 1985). The $\mathrm{VT}^{+}$strains were lactose-fermenting with the exception of the strain of serotype O163:H19. The $\mathrm{VT}^{+}$strains of serogroup $\mathrm{O} 157$ failed to ferment sorbitol after overnight incubation, which is in agreement with previous reports (Johnson et al., 1983; Wells et al., 1983); the $\mathrm{VT}^{+}$strains of other serogroups did ferment sorbitol. The $\mathrm{VT}^{+}$strains of serogroup $\mathrm{O} 157$ were sensitive to all the antimicrobial agents tested. The rough $\mathrm{VT}^{+}$strain of $\mathrm{H}-$ type 51 was resistant to streptomycin, sulphathiazole and tetracycline; the $\mathrm{VT}^{+} \mathrm{O} 153: \mathrm{H} 25$ strain was resistant to ampicillin, streptomycin and sulphathiazole. The remaining three $\mathrm{VT}^{+}$strains were fully sensitive.

In phase 1 , all the colonies of $E$. coli tested from 12 specimens were $\mathrm{VT}^{-}$in the tissue-culture test. These strains belonged to 27 different serogroups and none produced ST or LT. They included three strains belonging to the enteropathogenic (EPEC) serogroups O18ac, O86 and O128. None of these strains hybridised with either of the DNA probes for VT. However in phase 2 colonies from the faeces of patient 24 that hybridised with the VT1 probe failed to produce VT in the Vero-cell test (table II).

The $2 \mathrm{~kb}$ probe for VT2 was used in hybridisation tests with colonies on primary plating. In addition to the VT2 sequences this probe contains flanking phage DNA that is shared by some VT1-encoding phages (Willshaw et al., 1987). Subsequently the more specific $0.85 \mathrm{~kb}$ AvaI-Pst I probe for VT2 became available and the $\mathrm{VT}^{+}$strains were retested. Twenty strains had hybridised with the $2 \mathrm{~kb}$ probe and 19 of these hybridised with the $0.85 \mathrm{~kb}$ probe also. The strain that failed to hybridise with the $0.85 \mathrm{~kb}$ probe was the $\mathrm{O} 26: \mathrm{H} 11$ strain from patient 45 . This strain therefore hybridised with the VT1 probe only (table II).

\section{Examination of successive faecal specimens}

For four patients more than one faecal specimen was available for study. Patient 11 suffered from diarrhoea and the first specimen was taken 3 days after the onset of diarrhoea. This specimen (shown in table I) contained free VT at a titre of 40 , and 38 of the $40 \mathrm{E}$. coli colonies tested were $\mathrm{VT}^{+}$. In two subsequent specimens taken on days 6 and 7, VTEC colonies were not found ( 0 out of 40 colonies for each specimen) and VT was not detected. Patient 23 had been admitted to hospital with bloody diarrhoea and 7 of 40 colonies from the first faecal specimen were VTEC and VT was present at a titre of 40 (shown in table I). However, all of 30 colonies were $\mathrm{VT}^{-}$from a second specimen taken one day later, although VT at a titre of 40 was still present. Patient 41 had also suffered from bloody diarrhoea and the first specimen (shown in table II) had yielded VTEC ( 3 of 17 colonies) and VT at a titre of 780000 . Three other specimens from patient 41 were studied, taken 1, 2 and 9 days after the first. VTEC strains were not found in any of these either by picking colonies (none of 40,25 and 35 colonies respectively) or by testing with the probes. It was also observed that the VT titre had decreased to 20 , 20 and 0 respectively. Five of 40 colonies tested from the first faecal specimen from patient 45 were $\mathrm{VT}^{+}$and VT was detected at a titre of 300000 (table II); in a second specimen taken two days later, VTEC colonies were not detected by probes or by direct picking but VT was still present at the high titre of 300000 .

\section{Neutralisation of faecal cytotoxin}

Faecal filtrates which were positive for VT were 
stored at $-10^{\circ} \mathrm{C}$. When specific antisera to Shiga toxin (VT1) and VT2 became available these filtrates were tested but only four, from patients 20 , 41,45 and 48 , were still cytotoxic. The activity of filtrates from patients 20 and 41 was neutralised by anti-VT2 serum but not by serum against Shiga toxin; the faecal specimens from these patients had yielded VTEC, of serogroups O153 and O157 respectively, hybridising only with the VT2 probe. The activity of the filtrate from patient 45 was neutralised by the serum against Shiga toxin but not by the anti-VT2 serum; the faecal specimen of this patient had yielded a strain of $\mathrm{O} 26$ hybridising only with the VT1 probe. The activity of the filtrate from patient 48 was not neutralised by either antiserum alone but was neutralised when both antisera were used together; a strain of 0157 hybridising with both VT1 and VT2 probes had been isolated from this faecal specimen.

\section{Discussion}

Karmali et al. (1983) first reported an association between HUS and infection with $\mathrm{VT}^{+}$strains of $E$. coli. In a confirmatory study (Karmali et al., 1985) of 40 children who had developed HUS between September 1980 and September 1983, they isolated VTEC from 12 faecal specimens and free faecal VT without VTEC in a further 12 specimens. The $\mathrm{VT}^{+}$strains belonged to seven serotypesO26:H11, O111:H8, O111:H - O113:H21, O121:H19, O145:H - and O157:H7--and one strain was rough and non-motile. We have now shown a significant association between VTEC infection and HUS in many areas of the United Kingdom. $\mathrm{VT}^{+}$strains were isolated from the faeces of 19 of the 66 children studied and free faecal VT was detected in another three in the absence of VTEC. VTEC strains of several serotypes were isolated-O26:H11, O104: $\mathrm{H} 2$, O153:H25, O157:H7, O157:H - O163:H19 and O rough:H51 - but with the exception of $\mathrm{O} 157: \mathrm{H} 7$ and $\mathrm{O} 26: \mathrm{H} 11$, they were not the same as those identified in the Canadian study (Karmali et al., 1985). E. coli O157:H7 was the most common serotype, being found in 14 cases.

Strains of $E$. coli $\mathrm{O} 157$ producing either VT2 only or producing both VT1 and VT2 were detected previously (Scotland et al., 1985); additional strains belonging to these groups were identified in the present study. Four strains belonging to serogroups other than 0157 hybridised with the VT2 probe and one with the VT1 probe.
One strain hybridised with the VT1 probe but did not produce VT (table II). However, when this strain was tested with another VT1 probe comprising a different restriction fragment of the cloned VT1 sequences from H19 (Willshaw et al., 1987), no homology was detected. This suggests that the strain had incomplete VT sequences. For all other strains there was complete agreement between the two tests used for VT and VT production was detected reliably in culture supernates without the use of a special iron-depleted medium or sonication as used in some studies (O'Brien et al., 1982; Cleary et al., 1985).

Several methods have been proposed for improving the detection of VTEC in faeces. Our results show that if a preliminary screening is based on sorbitol agar (Farmer and Davis, 1985), VT ${ }^{+}$ bacteria belonging to serogroups other than 0157 would be missed. By use of the specific DNA probes it was possible to detect colonies of VTEC that were present in numbers as small as one in 1200 colonies. The sensitivity of the method probably accounts for the detection of $\mathrm{VT}^{+}$bacteria in the absence of free VT, in contrast to the findings of Karmali et al. (1985). However since free VT was sometimes found in the absence of $\mathrm{VT}^{+}$bacteria it seems preferable to use both techniques when possible.

No direct relationship was found between the titre of VT in faeces and the proportion of $\mathrm{VT}^{+}$ colonies present. Possible explanations for this include problems arising from the handling or storing of the samples before they are examined. Importantly the examination of more than one specimen from some patients showed that significant changes in the proportion of $\mathrm{VT}^{+}$colonies occurred within days. This was also noted in cases of haemorrhagic colitis by Riley et al. (1983), and the observation needs further investigation.

Neutralisation tests with specific antisera showed that VT1 or VT2 could be present alone or together in the faeces. The toxins found correlated with the probe results on the VTEC isolated from each specimen. This is the first report which specifically identifies these two particular Vero cytotoxins in vivo.

This study has confirmed an association between some cases of HUS in infants and young children and infection with $\mathrm{VT}^{+} E$. coli. A prospective case control study is now under way in order to identify specific risk factors and to elucidate the epidemiology of the disease.

We thank colleagues who sent specimens for this study. 


\section{REFERENCES}

Anderson E S, Threlfall E J 1974 The characterisation of plasmids in the enterobacteria. Journal of Hygiene 72 : 471487.

Cleary T G, Mathewson J J, Faris E, Pickering L K 1985 Shigalike cytotoxin production by enteropathogenic Escherichia coli serogroups. Infection and Immunity 47:335-337.

Cowan S T 1974 Cowan and Steel's manual for the identification of medical bacteria, 2nd edn. Cambridge University Press, Cambridge.

Day N P, Scotland S M, Rowe B 1981 Comparison of an HEp-2 tissue culture test with the Sereny test for detection of enteroinvasiveness in Shigella spp. and Escherichia coli. Journal of Clinical Microbiology 13:596-597.

Drummond K N 1985 Hemolytic uremic syndrome-then and now. New England Journal of Medicine 312: 116-118.

Farmer J J, Davis B R 1985 H7 Antiserum-sorbitol fermentation medium: a single tube screening medium for detecting Escherichia coli $\mathrm{O} 157: \mathrm{H} 7$ associated with hemorrhagic colitis. Journal of Clinical Microbiology 22:620-625.

Gross R J, Rowe B 1985 Serotyping of Escherichia coli. In: Sussman M (ed) The virulence of Escherichia coli. Reviews and Methods. Academic Press, London, pp 345-363.

Gross R J, Scotland S M, Rowe B 1976 Enterotoxin testing of Escherichia coli causing epidemic infantile enteritis in the UK. Lancet 1:629-631.

Gully P R 1984 Haemolytic-uraemic syndrome: epidemiology and report of an outbreak. Journal of the Royal Society of Health 104: 214-217.

Huang A et al. 1986 Cloning and expression of the genes specifying Shiga-like toxin production in Escherichia coli H19. Journal of Bacteriology $166: 375-379$.

Johnson W M, Lior H, Bezanson G S 1983 Cytotoxic Escherichia coli $\mathrm{O} 157: \mathrm{H} 7$ associated with haemorrhagic colitis in Canada. Lancet $1: 76$

Karmali M A, Petric M, Lim C, Fleming P C, Arbus G S, Lior $\mathrm{H} 1985$ The association between idiopathic hemolytic uremic syndrome and infection by Verotoxin-producing Escherichia coli. Journal of Infectious Diseases 151:775-782.

Karmali M A, Petric M, Louie S, Cheung R 1986 Antigenic heterogeneity of Escherichia coli Verotoxins. Lancet 1:164 165.

Karmali M A, Steele B T, Petric M, Lim C 1983 Sporadic cases of haemolytic-uraemic syndrome associated with faecal cytotoxin and cytotoxin-producing Escherichia coli in stools. Lancet 1:619-620.

Konowalchuk J, Dickie N, Stavric S, Speirs J I 1978a Properties of an Escherichia coli cytotoxin. Infection and Immunity 20:575-577.

Konowalchuk J, Dickie N, Stavric S, Speirs J I 1978b Comparative studies of five heat-labile toxic products of Escherichia coli. Infection and Immunity 22: 644-648.

Konowalchuk J, Speirs J I, Stavric S 1977 Vero response to a cytotoxin of Escherichia coli. Infection and Immunity 18 : 775 779.

Koster F et al. 1978 Hemolytic-uremic syndrome after shigellosis : Relation to endotoxemia and circulating immune complexes. New England Journal of Medicine 298: 927-933.
Levin M, Barratt J M 1984 Haemolytic uraemic syndrome. Archives of Disease in Childhood 59:397-400.

Newland J W, Strockbine N A, Miller S F, O'Brien A D, Holmes R K 1985 Cloning of Shiga-like toxin structural genes from a toxin converting phage of Escherichia coli. Science 230: 179-181.

O'Brien A D, LaVeck G D, Thompson M R, Formal S B 1982 Production of Shigella dysenteriae type 1-like cytotoxin by Escherichia coli. Journal of Infectious Diseases 146:763-769.

O'Brien A D, Newland J W, Miller S F, Holmes R K, Smith H W, Formal S B 1984 Shiga-like toxin-converting phages from Escherichia coli strains that cause hemorrhagic colitis or infantile diarrhea. Science 226:694-696.

Rahaman M M, Jamial Alam A K M, Islam M R, Greenough W B, Lindenbaum J 1975 Shiga bacillus dysentery associated with marked leukocytosis and erythrocyte fragmentation. Johns Hopkins Medical Journal 136:65-70.

Riley L W et al. 1983 Hemorrhagic colitis associated with a rare Escherichia coli serotype. New England Journal of Medicine 308: 681-685.

Scotland S M, Day N P, Rowe B 1980 Production of a cytotoxin affecting Vero cells by strains of Escherichia coli belonging to traditional enteropathogenic serogroups. FEMS Microbiology Letters 7:15-17.

Scotland S M, Smith H R, Rowe B 1985 Two distinct toxins active on Vero cells from Escherichia coli O157. Lancet 2:885-886.

Scotland S M, Smith H R, Willshaw G A, Rowe B 1983 Vero cytotoxin production in strain of Escherichia coli is determined by genes carried on bacteriophage. Lancet 2: 216 .

Smith H R, Day N P, Scotland S M, Gross R J, Rowe B 1984 Phage-determined production of Vero cytotoxin in strains of Escherichia coli serogroup 0157. Lancet 1 : 1242-1243.

Smith H W, Green P, Parsell Z 1983 Vero cell toxins in Escherichia coli and related bacteria: transfer by phage and conjugation and toxic action in laboratory animals, chickens and pigs. Journal of General Microbiology 129:3121-3137.

Taylor C M, White R H R, Winterborn M H, Rowe B 1986 Haemolytic-uraemic syndrome: clinical experience of an outbreak in the West Midlands. British Medical Journal 292: 1513-1516.

Von Gasser C, Gautier E, Steck A, Siebenmann R E, Oechslin R 1955 Hämolytisch-urämische syndrome: bilaterale nierenrindennekrosen bei akuten erworbenen hämolytischen anämien. Schweizerische Medizinische Wochenschrift 85:905-909.

Wells J G et al. 1983 Laboratory investigation of hemorrhagic colitis outbreaks associated with a rare Escherichia coli serotype. Journal of Clinical Microbiology 18:512-520.

Willshaw G A, Smith H R, Scotland S M, Field A M, Rowe B 1987 Heterogeneity of Escherichia coli phages encoding Vero cytotoxins: Comparison of cloned sequences determining VT1 and VT2 and development of specific gene probes. Journal of General Microbiology 133: 1309-1317.

Willshaw G A, Smith H R, Scotland S M, Rowe B 1985 Cloning of genes determining the production of Vero cytotoxin by Escherichia coli. Journal of General Microbiology 131 : 30473053. 